\title{
La Familia y la Construcción del Género: estudios de la Universidad Internacional SEK
}

\author{
PhD. Nadia Margarita Rodríguez Jiménez \\ Universidad Internacional SEK, UISEK \\ nadia.rodriguez@uisek.edu.ec \\ Quito, Ecuador \\ https://orcid.org/0000-0002-0657-2873
}

PhD. Ana Rosa di Gravia de Granadillo Universidad Internacional SEK, UISEK ana.digravia@uisek.edu.ec Quito, Ecuador https://orcid.org/0000-0002-8025-8196

\section{Editorial}

La Universidad Internacional SEK (UISEK), fue fundada en el año 1993 bajo el auspicio de la Institución Internacional SEK en Quito, Ecuador, con la presencia en 15 países de Europa, América y África, siendo una de las redes más grandes de educación laica privada del mundo. Nuestra Universidad, arranca su proyecto académico con la facultad de Ciencias Económicas y Administrativas, Ingeniería en Medio Ambiente, Turismo y Patrimonio Cultural, en el año 1994, la Facultad de Ciencias Sociales y Jurídicas, en el año 1996, la Facultad de Arquitectura y Urbanismo, en el año 1998, se crea la Facultad de Ciencias de la Información, en el año 2001, abre sus puertas la facultad de Psicología, así como Seguridad y Salud Ocupacional, y en el año 2008, se consolida el proyecto de la facultad de Ingeniería Mecánica. En estos últimos 3 años, la Universidad se ha restructurado creando el UISEK Business School y el Digital School. Con ello se afianza el proyecto académico sobresaliendo en múltiples campos de formación de profesionales.

Hasta la fecha, la UISEK ha reforzado sus estrategias en un mejoramiento continuo y fortaleciendo su proyecto educativo bajo el ideal de ¡SER MEJORES!. Con un modelo educativo orientado a la calidad y la educación personalizada, priman los valores del respeto, la integración y la 
educación liberal. De igual forma, la UISEK ha intentado estar a la vanguardia en la creación de una oferta académica pertinente y respondiendo a las necesidades de su entorno. Por ello, hoy contamos con 14 carreras de pregrado, 16 maestrías y numerosas ofertas de actualización a través de nuestro centro de educación continua. El dinamismo y el compromiso con el desarrollo del capital humano en el país han marcado nuestra andadura. Estamos en continua renovación al ritmo de los avances contemporáneos, los proyectos de desarrollo del país y de la sociedad en general.

En esta oportunidad, la Revista Scientific (e-ISSN: 2542-2987), en su edición especial, presenta diez (10) artículos originales de nuestros estudiantes y docentes de la Carrera de Psicología y la Maestría de Psicoterapia, que forman parte de la Facultad de Ciencias del Trabajo y del Comportamiento Humano. Con gran gratitud hacia la revista y sus editores, y con mucho orgullo por nuestro proyecto formativo, damos a conocer este material inédito, fruto de las investigaciones, interacciones y del esfuerzo de nuestra comunidad académica.

Para la Universidad, es un privilegio poder entregar como resultado del proceso formativo, artículos científicos de alta calidad que son el producto del intercambio formativo en las aulas. No es fácil culminar un programa de formación llegando a su más alto resultado académico, que es graduarse mediante la realización de un artículo científico original publicado, por ello, este número especial representa los principios y valores de formación con los máximos estándares de calidad, que profesamos en la UISEK.

La Maestría en Psicoterapia nace en el año 2018 con la misión de especializar a los profesionales de la psicología en las distintas escuelas de atención terapéutica, dándoles diversas herramientas para la atención psicológica. Está maestría se ha caracterizado por ser la primera en el país en su género y ya cuenta con un prestigio relevante por la calidad de sus docentes y de la formación. Dicha calidad queda reflejada en los artículos que se 
presentan en este compendio, en el cual nuestros estudiantes y alumnos han trabajado críticamente sobre diversos problemas que nos deben preocupar a todos en la sociedad. Desde la perspectiva de contribuir en la construcción de soluciones a los problemas psicosociales, estas investigaciones profundizan y aportan datos que, como académicos, nos permiten proponer acciones, asesorar políticas y visibilizar problemáticas que contribuyan a mejorar la salud mental de las personas.

En el contexto actual en el que nos enfrentamos a una fuerte crisis económica y con los efectos generados por la pandemia, el aislamiento, distanciamiento y las secuelas que quedarán en adelante, debe considerarse primordial, fortalecer la reflexión sobre los problemas relacionados a la salud mental que se pueden desencadenar: como la Violencia, depresión, ansiedad, suicidio, y consumo de sustancias. Son todos aspectos que se están recrudeciendo en este tiempo y por ello nuestros estudiantes, docentes e investigadores, están muy activos desarrollando análisis y reflexiones que puedan contribuir en este contexto tan complejo. La salud mental se convierte en un problema de salubridad pública y debemos alertar sobre las consecuencias y asesorar referente las acciones, la toma de decisiones y las medidas a tomar, por ello, estos aportes están más vigentes que nunca.

En esta edición especial se presentan los conocimientos y el análisis de construcciones sociales colectivas, como lo es el significado de violencia, violencia de género y violencia familiar. Estos conceptos son uno de los mayores problemas que afectan nuestra sociedad, nada nuevo, pero revisten hoy de una particularidad condición, es por lo que para Vaca y Díaz (2009); y Barbosa (2014), citados por Barbosa, Marcela, Daría y Rivera (2017): "la violencia es un asunto tanto histórico como cultural y que los discursos dominantes que se trasmiten de manera intergeneracional son claves para la comprensión de dicho fenómeno" (pág. 118). En atención a lo que señalan estos autores, los estudios que intenten comprender o explicar conductas en 
mujeres víctimas de violencia, mujeres víctimas de violencia de género y/o violencia familiar, deben ser contextualizados en los discursos de poder transmitidos entre generaciones y entre contextos o espacios particulares 0 específicos.

La introducción de la variable género dentro del concepto de violencia en psicología, bajo la mirada construccionista, cobra vigencia cuando Mahalik (2000), citado por Rivas-Diez, Brabete y Sánchez-López (2018): la define “[...] como un conjunto de reglas que guían y prescriben lo que los hombres y las mujeres deben hacer, pensar o sentir" (pág. 118). De esta manera, para Jodelet y Guerrero (2000): la investigación del conocimiento científico en el ámbito de la psicología; análisis de la violencia, género, relaciones parentales, familia, riesgos psicosociales se develan en los discursos, en las experiencias prácticas, en las nociones de sentido común y en las representaciones sociales, interactuando así lo histórico, lo social y lo cultural.

En las afirmaciones señaladas por Paula-Pérez (2018): no escapan las investigaciones recientes sobre autismo, donde se concluye en la diversidad de factores que deben ser tomados en cuenta para su análisis; condiciones genéticas, trastornos del neurodesarrollo, factores epigenéticos, anomalías en la estructura y funcionamiento del nivel neurobiológico, pero muy particularmente, los riesgos ambientales que tienen que ver con la calidad de vida de la madre durante del embarazo y con los factores de urbanidad.

Tomando en consideración estos aportes, podemos afirmar según Valle (2018): que la intervención del psicólogo, sus estrategias de intervención y apoyo terapéutico, independientemente de las teorías a las que se acojan en la solución de dificultades que nos afecta y que intervienen directamente en los estados y problemas de la salud mental de todos, tienen que conjugar las variables clínicas propiamente y las variables sociales, que configuran la intervención desde la mirada de las construcciones de representación social y nociones de sentido común relacionando lo histórico y lo socio-cultural; 
tenemos entonces que discriminar entre los problemas de conducta y los trastornos de salud mental, es un reto indispensable para los psicólogos de hoy tener un acercamiento entre lo clínico y lo social.

Asumiendo este reto, los maestrantes adscritos a la Maestría en Psicoterapia, abordan distintas problemáticas relacionadas con la intervención y la labor de los psicólogos, exhibiendo un aporte importante en el área a tratar. En el campo abordado, contamos con la propuesta de Inés Margarita Mantilla Posso; Yanitza Elizabeth Pavón Ipiales, a través de la instrucción del Rol de la familia en la construcción de la identidad de género en mujeres trans, determinando que este es vivido por las mujeres que se identifican dentro del colectivo transgénero, como una experiencia que supera el ámbito íntimoparticular y que es sentido como una reparación. Frente a esto, Elizabeth Alexandra Dávila Cueva; Mirian Isabel González Chicaiza; Diana Cristina Castellanos Vela; Janethcia del Rocío Játiva Morillo, presentan su Adaptación social a la comunidad educativa de niños venezolanos en situación de movilidad humana, la dinámica familiar y su relación con la resolución del duelo en los procesos de movilidad, en el caso de migrantes venezolanos.

Paralelamente, Janeth Rosario Medina Benavides; María Augusta Villena Morales; Elka Jacqueline Vargas Estupiñan, exponen su artículo Redes de apoyo en mujeres víctimas de violencia: un estudio desde el modelo transgeneracional, quienes analizan la violencia hacia las mujeres desde el modelo transgeneracional y su implicación en la construcción de procesos psíquicos. Contamos en este número con los aportes de Luís Gabriel Benalcázar Mancero; Paulo César Damián Carrión; Pamela Valeria Yarad Jeada, en el análisis de Mujeres víctimas de violencia de género en Ecuador: redes de apoyo y estrategias de afrontamiento, quienes analizan las redes de apoyo y las formas de afrontamiento de las mujeres ecuatorianas víctimas de violencia de genero.

En este mismo orden de ideas, Gloria Isabel Pinos Arízaga; Mayra 
Alexandra Moya Alulema; María de las Mercedes Bastidas Redín; Gabriela Alexandra Pazmiño Márquez, señalan la Relación entre las habilidades parentales $y$ el bajo rendimiento académico en una muestra de adolescentes, examinando la relación entre las habilidades parentales y el bajo rendimiento académico de adolescentes de una unidad educativa ubicada en la provincia de Santo Domingo de los Tsáchilas, Ecuador. Por su parte, Joffre David Agualongo Amangandi; Diana Isabel Robalino Robayo, manifiestan las Consecuencias del consumo de drogas en las Funciones Ejecutivas en adolescentes y jóvenes adultos, indagan sobre las habilidades ejecutivas alteradas debido al consumo de drogas en las personas que asisten al Área Ambulatorio Intensiva del Centro de Salud de la ciudad de Latacunga, Ecuador.

Adicionalmente, Camila Belén Muñoz Aguirre, quien responde al desarrollo en Función de la empatía en el trabajo de psicólogos y psicoterapeutas, con la empatía como herramienta para el ejercicio de la psicología. Enfocándonos en los temas relacionados a la infancia, contamos con la investigación de Silvia de los Ángeles Armas Arboleda; Mónica Patricia Cansignia Alcocer; Elena Narcisa Díaz Mosquera, El vínculo figura cuidadora-niño en casos de autismo, explorando las características de la interacción de cuatro figuras cuidadoras en niños con Trastorno Autista y proponen una guía de fortalecimiento de vínculos, de modo que se promueva el desarrollo de los niños.

Si tocamos lo relacionado a la atención, Nathalie Soledad López Arroyo; Erika Elizabeth Torres Rueda; Carmen Eugenia Mora Mora; Esteban Ricaurte Ricaurte, identifican la Evaluación de riesgos psicosociales en servidores policiales especializados, en el personal directivo y técnico operativo de la Dirección Nacional de Delitos contra la Vida, Muertes Violentas, Desapariciones, Extorsión y Secuestro (DINASED), por su vulnerabilidad a factores de riesgo al encontrarse en contacto permanente con el sufrimiento 
de las personas que han pasado por una situación en la desaparición de un familiar, muerte violenta, tentativa de asesinato o secuestro. Finalmente, Joel Santiago Barreno López; Claudio Danilo Pazmiño Tirado; Luís Alfonso Iriarte Pérez, abordan el tema de Predisposición al consumo de sustancias en aspirantes a la carrera militar, en la problemática del consumo de Sustancias Psicoactivas en un grupo específico de los aspirantes a la carrera militar.

Con estos aportes importantes presentados en esta edición especial, estamos seguros de haber contribuido en la formación de las competencias y habilidades investigativas de todos estos profesionales, ique brillantemente han presentado los resultados de sus investigaciones!, y a la vez, se ha producido un conocimiento científico significativo dentro del área de la psicología, incidiendo positivamente en el área de la salud mental en el Ecuador, sobre todo, mostrando trabajos con propuestas y estrategias de intervención en problemas de actualidad. Finalmente, esperamos que esta entrega beneficie a los profesionales y estudiantes que tengan acceso a esta publicación y que, además, contribuyan de alguna manera en la toma de decisiones de instituciones gubernamentales y privadas dentro de la región, favoreciendo la salud mental de niños, mujeres, trabajadores y de la sociedad en su conjunto.

Palabras clave: familia; psicoterapia; psicólogo; editorial.

Fecha de Recepción: 16-04-2020
Fecha de Aceptación: 15-06-2020
Fecha de Publicación: 05-08-2020 
Instituto Internacional de Investigación y Desarrollo Tecnológico Educativo INDTEC, C.A.

DOI: https://doi.org/10.29394/Scientific.issn.2542-2987.2020.5.E.0.9-24

OAI-PMH: http://www.indteca.com/ojs/index.php/Revista Scientific/oai

\section{The Family and the Construction of Gender: studies from SEK International University}

\section{Editorial}

SEK International University (UISEK), was founded in 1993 under the auspices of the SEK International Institution in Quito, Ecuador, with a presence in 15 countries in Europe, America and Africa, being one of the largest networks of secular education deprived of the world. Our University starts its academic project with the Faculty of Economic and Administrative Sciences, Engineering in the Environment, Tourism and Cultural Heritage, in 1994, the Faculty of Social and Legal Sciences, in 1996, the Faculty of Architecture and Urbanism , in 1998, the Faculty of Information Sciences was created, in 2001, the Faculty of Psychology, as well as Occupational Safety and Health, opened its doors, and in 2008, the project of the Faculty of Mechanical Engineering. In these last 3 years, the University has been restructured creating the UISEK Business School and the Digital School. This strengthens the academic project, excelling in multiple fields of professional training.

To date, UISEK has reinforced its strategies in continuous improvement and strengthening its educational project under the ideal of BEING BETTER !. With a quality-oriented educational model and personalized education, the values of respect, integration and liberal education prevail. Similarly, UISEK has tried to be at the forefront in creating a relevant academic offer and responding to the needs of its environment. For this reason, today we have 14 undergraduate degrees, 16 master's degrees and numerous upgrade offers through our continuing education center. The dynamism and commitment to the development of human capital in the country have marked our journey. We are in continuous renewal at the rate of contemporary advances, the development projects of the country and of society in general.

On this occasion, the Revista Scientific (e-ISSN: 2542-2987), in its special edition, presents ten (10) original articles from our students and 
teachers of the Psychology Degree and the Psychotherapy Master, who are part of the Faculty of Labor and Human Behavior Sciences. With great gratitude towards the magazine and its editors, and with great pride in our training project, we present this unpublished material, the fruit of the research, interactions and effort of our academic community.

For the University, it is a privilege to be able to deliver, as a result of the training process, high-quality scientific articles that are the product of training exchange in the classroom. It is not easy to complete a training program reaching its highest academic result, which is graduating by completing an original scientific article published, therefore, this special issue represents the principles and values of training with the highest quality standards, which we profess at UISEK.

The Master in Psychotherapy was born in 2018 with the mission of specializing psychology professionals in the different schools of therapeutic care, giving them various tools for psychological care. This master's degree has been characterized by being the first in the country of its kind and it already has a relevant prestige for the quality of its teachers and training. This quality is reflected in the articles presented in this compendium, in which our students have worked critically on various problems that should concern us all in society. From the perspective of contributing to the construction of solutions to psychosocial problems, these investigations deepen and provide data that, as academics, allows us to propose actions, advise on policies, and make visible problems that contribute to improving people's mental health.

In the current context in which we are facing a strong economic crisis and with the effects generated by the pandemic, isolation, distancing and the consequences that will follow, it should be considered essential to strengthen reflection on problems related to mental health that can be triggered: such as violence, depression, anxiety, suicide, and substance use. These are all aspects that are intensifying at this time and for this reason our students, 
teachers and researchers are very active in developing analyzes and reflections that can contribute in this complex context. Mental health becomes a public health problem and we must alert about the consequences and advise regarding actions, decision-making and the measures to be taken, therefore, these contributions are more current than ever.

This special edition presents the knowledge and analysis of collective social constructions, such as the meaning of violence, gender violence and family violence. These concepts are one of the biggest problems that affect our society, nothing new, but today they have a particular condition, which is why for Vaca and Díaz (2009); and Barbosa (2014), cited by Barbosa, Marcela, Daría and Rivera (2017): "violence is both a historical and a cultural issue and that the dominant discourses that are transmitted in an intergenerational way are key to understanding this phenomenon" (p. 118). In response to what these authors point out, studies that attempt to understand or explain behaviors in women victims of violence, women victims of gender violence and / or family violence, must be contextualized in the power discourses transmitted between generations and between contexts or particular or specific spaces.

The introduction of the gender variable within the concept of violence in psychology, under the constructionist perspective, becomes effective when Mahalik (2000), cited by Rivas-Diez, Brabete y Sánchez-López (2018): defines it "[...] as a set of rules that guide and prescribe what men and women should do, think or feel" (p. 118). Thus, for Jodelet and Guerrero (2000): the investigation of scientific knowledge in the field of psychology; Analysis of violence, gender, parental relationships, family, psychosocial risks are revealed in discourses, in practical experiences, in common sense notions and in social representations, thus interacting the historical, the social and the cultural.

In the statements pointed out by Paula-Pérez (2018): recent research on autism does not escape, where it is concluded in the diversity of factors that must be taken into account for its analysis; genetic conditions, 
neurodevelopmental disorders, epigenetic factors, abnormalities in the structure and functioning of the neurobiological level, but most particularly, the environmental risks that have to do with the quality of life of the mother during pregnancy and with urban factors.

Taking into account these contributions, we can affirm according to Valle (2018): that the intervention of the psychologist, his intervention strategies and therapeutic support, independently of the theories that are accepted in the solution of difficulties that affect us and that directly intervene in the states and problems of everyone's mental health have to combine the clinical variables themselves and the social variables, which configure the intervention from the perspective of the constructions of social representation and common sense notions relating the historical and the socio-cultural; So we have to discriminate between behavioral problems and mental health disorders, it is an indispensable challenge for today's psychologists to have an approach between the clinical and the social.

Assuming this challenge, the teachers assigned to the Master in Psychotherapy, address different problems related to the intervention and the work of psychologists, exhibiting an important contribution in the area to be treated. In the field addressed, we have the proposal of Inés Margarita Mantilla Posso; Yanitza Elizabeth Pavón Ipiales, through the instruction of the Role of the family in the construction of gender identity in trans women, determining that this is lived by women who identify themselves within the transgender community, as an experience that goes beyond the intimateparticular sphere and that is felt as a repair. Against this, Elizabeth Alexandra Dávila Cueva; Mirian Isabel González Chicaiza; Diana Cristina Castellanos Vela; Janethcia del Rocío Játiva Morillo, present their Social adaptation to the educational community of Venezuelan children in situations of human

mobility, family dynamics and its relationship with grief resolution in mobility processes, in the case of Venezuelan migrants. 
Parallel, Janeth Rosario Medina Benavides; María Augusta Villena Morales; Elka Jacqueline Vargas Estupiñan, expose their article Support networks in women victims of violence: a study from the transgenerational model, who analyze violence against women from the transgenerational model and its implication in the construction of psychic processes. We have in this number the contributions of Luís Gabriel Benalcázar Mancero; Paulo César Damián Carrión; Pamela Valeria Yarad Jeada, in the analysis of Women victims of gender violence in Ecuador: support networks and coping strategies, who analyze the support networks and the ways of coping of Ecuadorian women victims of gender violence.

In this same order of ideas, Gloria Isabel Pinos Arízaga; Mayra Alexandra Moya Alulema; María de las Mercedes Bastidas Redín; Gabriela Alexandra Pazmiño Márquez, point the Relationship between parenting skills and low academic performance in a sample of adolescents, examining the relationship between parental skills and poor academic performance of adolescents from an educational unit located in the province of Santo Domingo of the Tsáchilas, Ecuador. For his part, Joffre David Agualongo Amangandi; Diana Isabel Robalino Robayo, manifest the Consequences of drug use on executive functions in adolescents and young adults, they inquire about the executive skills altered due to drug consumption in people who attend the Intensive Outpatient Area of the Health Center of the city of Latacunga, Ecuador.

Additionally, Camila Belén Muñoz Aguirre, who responds to development in Role of empathy in the work of psychologists and psychotherapists, with empathy as a tool for the exercise of psychology. Focusing on issues related to childhood, we have research from Silvia de los Ángeles Armas Arboleda; Mónica Patricia Cansignia Alcocer; Elena Narcisa Díaz Mosquera, The caregiver-child bond in autism cases, exploring the characteristics of the interaction of four caregivers in children with Autistic 
Disorder and proposing a guide to strengthen ties, so as to promote the development of children.

If we touch what is related to attention, Nathalie Soledad López Arroyo; Erika Elizabeth Torres Rueda; Carmen Eugenia Mora Mora; Esteban Ricaurte Ricaurte, identify the Psychosocial risk assessment in specialized police servers, in the executive and technical personnel of the National Directorate of Crimes against Life, Violent Deaths, Disappearances, Extortion and Kidnapping (DINASED), for their vulnerability to risk factors as they are in permanent contact with the suffering of people who have passed for a situation in the disappearance of a relative, violent death, attempted murder or kidnapping. Finally, Joel Santiago Barreno López; Claudio Danilo Pazmiño Tirado; Luís Alfonso Iriarte Pérez, address the issue of Predisposition to substance use in applicants to the military career, in the problem of the consumption of Psychoactive Substances in a specific group of applicants to the military career.

With these important contributions presented in this special edition, we are sure to have contributed to the training of the investigative skills and competences of all these professionals, who have brilliantly presented the results of their research! And, at the same time, knowledge has been produced Significant scientist in the area of psychology, positively influencing the area of mental health in Ecuador, especially, showing work with proposals and intervention strategies in current problems. Finally, we hope that this installment benefits the professionals and students who have access to this publication and, in addition, contribute in some way to the decision-making of government and private institutions within the region, promoting the mental health of children, women, workers and society as a whole.

Keywords: family; psychotherapy; psychologist; publisher.

Date Received: 16-04-2020
Date Acceptance:

15-06-2020
Date Publication:

05-08-2020 


\section{Referencias}

Barbosa, A., Marcela, G., Daría, G., \& Rivera, E. (2017). Reflexión socioconstruccionista y política en torno a la violencia familiar. Tesis Psicológica, 12(1), 116-126, e-ISSN: 1909-8391. Recuperado de: http://www.redalyc.org/articulo.oa?id=139057282005

Jodelet, D., \& Guerrero, A. (2000). Develando la cultura: Estudios en representaciones sociales. Primera edición, ISBN: 968-36-8391-6. México, D.F.: Universidad Nacional Autónoma de México.

Paula-Pérez, I. (2018). Convergencias y divergencias genéticas, neurobiológicas y ambientales entre el autismo y el espectro de la esquizofrenia. Anuario de Psicología, 48(3), 105-112, e-ISSN: 00665126. Recuperado de: https://doi.org/10.1016/i.anpsic.2018.11.001

Rivas-Diez, R., Brabete, A., \& Sánchez-López, M. (2018). Evaluación de la Variable Género: CFNI en Mujeres Chilena. RIDEP: Revista Iberoamericana de Diagnóstico y Evaluación - e Avaliação Psicológica, 3(48), 117-125, e-ISSN: 2183-6051. Recuperado de:

https://doi.org/10.21865/RIDEP48.3.10

Valle, J. (2018). La intervención del psicólogo en los servicios sociales de familia e infancia: Evolución y retos actuales. Papeles del Psicólogo, 39(2), 104-112, e-ISSN: 1886-1415. Recuperado de:

http://www.redalyc.org/articulo.oa?id=77855949004 


\section{Nadia Margarita Rodríguez Jiménez e-mail: nadia.rodriguez@uisek.edu.ec}

Nacida en Bogotá, Colombia, el 7 de mayo del año 1975.

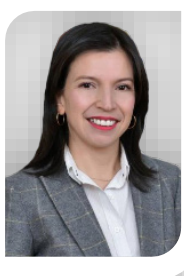
Antropóloga de la Universidad de los Andes de Colombia (UNIANDES); Máster en Sociología y Antropología de la Universidad de París 1 Panthéon-Sorbonne; y Doctora en Ciencias Sociales de lo contemporáneo de la misma universidad; Profesora investigadora en la Universidad del Rosario (UR); y Directora de la carrera de sociología; Directora de la investigación "Retos y perspectivas de la política de restitución de tierras en Colombia" desde el año 1997 al año 2011; Codirectora del Observatorio de Identidades, prácticas y políticas en el espacio rural colombiano; Consultora y asesora en desarrollo rural; Vicerrectora de la Universidad Internacional SEK (UISEK), en Ecuador; y actualmente Rectora desde el año 2018. 


\section{Ana Rosa di Gravia de Granadillo e-mail: ana.digravia@uisek.edu.ec}

Nacida en la ciudad de Caracas, Venezuela, el 9 de mayo

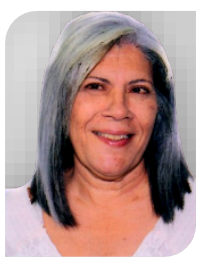
del año 1957. Lic. en Psicología en la Universidad Central de Venezuela (UCV); Magister en Investigación Educativa en la Universidad de Carabobo (UC); y Dra. en Ciencias de la Educación, línea Enseñanza y Aprendizaje de la Educación, en la Universidad Nacional Experimental Simón Rodríguez (UNESR); Docente Titular en la Universidad Internacional SEK (UISEK); Presidenta del Comité Editorial de la UISEK, Jefe del Programa de Investigación "Desarrollo y Transformación Social en la UISEK; Autora del libro "Cómo Formular un Problema de Investigación", UISEK (2019); y autora de diversos capítulos de libros y artículos en revistas indexadas; He participado en diferentes Congresos y Seminarios dentro del área de la psicología, la educación y la investigación. 